\title{
While the cat's away, will the mice play? Government-NGO relations and the politics of aid in Hungary
}

Krisztina Szabó, Balázs Szent-Iványi, and András Tétényi

Please cite as: Szabó, K., Szent-Iványi, B. and Tétényi, A. (2019): While the cat's away, will the mice play? Government-NGO relations and the politics of aid in Hungary. In Olivié, I. and Pérez, A. (eds) Aid Power and Politics. Abingdon, Routledge, Chapter 8.

\section{Introduction}

In pluralistic societies, interest groups play an important role in forming government policies. In the case of international development policy, a number of stakeholders beyond government actors are present in policy processes, including non-governmental organisations (NGOs), businesses, think tanks, academics, and other experts. This feature has already been described in other chapters of this volume, as it is seized in both theoretical analyses of IR (surveyed in Chapters 1 and 2) and empirical studies (Chapters 3 and 4 on the US and the UK, respectively) on the behaviour of donors. All of these actors have particular views on how much aid the government should give, to whom, through what channels, and according to what norms. Interestingly, however, these actors' impact on aid policy, and more broadly on the domestic politics of how international development policy is formulated, has received relatively little attention. Contributions in the literature have provided historical-institutional accounts of how aid policy develops in donor countries (see, e.g., Lancaster, 2006; Hoebink, 2011) and have examined the roles of legislatures (Milner \& Tingley, 2010) and political parties in those processes (Heppel \& Lightfoot, 2012). While some work has been done on the role of NGOs in the development policy processes of donor countries and organisations like the EU or World Bank (Elgström, 2000; Park, 2005; Szent-Iványi \& Lightfoot, 2016), most of the literature tends to conceptualise NGOs as implementers of foreign aid projects (e.g. Nunnenkamp \& Öhler, 2012; Sanchez Salgado, 2017), or else focusses on NGOs’ highly visible international campaigns (Busby, 2007) as opposed to their domestic policy advocacy.

This chapter aims to contribute to this literature by examining the possible relationships that can emerge between NGOs and governments, and it raises the question of how the nature of this relationship impacts the ability of NGOs to shape the government's international development policy. It uses an emerging European donor, Hungary, as a case study. While Hungary may not be a straightforward choice for 
examining donor government-NGO dynamics, it is surprisingly relevant as a case study. First, as a relatively new donor, Hungary provides lessons for other emerging donors, especially those from the Central and Eastern European (CEE) region, but also beyond. Second, as discussed below, there have been a number of significant changes in the relationship between the Hungarian government and NGOs over the past two decades, providing an interesting setting for examining how these changes have impacted the influence of NGOs.

Using insights from public choice theory and theories on government-NGO relations, the chapter presents a typology of these relations, and then applies it to the case of development NGOs in Hungary. Using an historical approach, the chapter focusses on the years between 2003 (when Hungary's international development policy was launched) and 2018. Three main conclusions emerge from this exercise. First, the government created partnerships with large service-provider NGOs, and it has generally co-opted or confronted smaller ones (see below). Second, during most of the period, relatively little domestic political and public attention was paid to international development; thus, the government had little incentive to react to the advocacy demands of NGOs or to engage in any policy reform. Third, reform was possible only after the government realised how it could fit international development policy into its wider foreign policy toolkit and took ownership of the policy.

The chapter is structured as follows. The "Theoretical considerations" section provides some conceptual insights on government-NGO relations. The "Relations between development NGOs and the Hungarian government" section uses those insights to analyse how relations evolved between the Hungarian government and development and humanitarian NGOs between 2003 and 2018. The final section offers some concluding remarks.

\section{Theoretical considerations}

In theory, Northern NGOs generally play two key sets of roles in the field of international development. First, they deliver services, which include the implementation of projects aimed at promoting development and poverty reduction in poor countries, along with projects in their home countries aimed at raising awareness on poverty and the associated global challenges (Steinberg, 2006). Second, NGOs have a key role in holding the government to account. They monitor the activities of governments to ensure that they meet legal, ethical, and moral standards, as well as internationally agreed commitments (Najam, 2000). NGOs also aim to shape government activity and to prod public policies towards a vision they consider correct. NGOs can thus be conceptualised as interest groups and "para-policy organisations" with the aim of bringing together actors for the purpose of putting particular social visions into practice 
(Najam, 1999). Some NGOs rely exclusively on private donations (including volunteers) to fund these activities, while others may use membership fees or engage in commercial activity. NGOs may also bid for grants from the state or international organisations, and, in some cases, they may enter into longerterm formal or informal arrangements with the state. It is well documented in the literature that such reliance on the state can compromise their advocacy role (Mosley, 2012).

Given the roles of NGOs, the relationship between them and governments is crucial and has an impact on the effectiveness of development NGOs in delivering international development objectives, and in influencing public policy strategies and means. One possible way of approaching this relationship is to compare how NGOs and the government prioritise policy goals, and how they choose policy instruments to achieve these goals. Hence, Najam's (2000) theory of the "four Cs" is used as a framework, arguing that the position of an NGO relative to the government is best understood through the degree of similarities or discrepancies in the means and goals of the two actors. The interests, priorities, external influences, and resources of governments and NGOs may diverge in some policy areas and converge in others, leading to four potential outcomes: (1) both actors seek similar ends with similar means (cooperation), (2) they seek dissimilar ends with dissimilar means (confrontation), (3) both seek similar ends but prefer dissimilar means (complementarity), and (4) both actors prefer similar means but for dissimilar ends (co-optation) (Najam, 2000).

In cases where there is agreement on the policy goals between the government and NGOs (cooperation or complementarity), we can expect certain forms of partnership to emerge between the two actors. Even if there are differences in the strategies applied (as in the case of complementarity), "ends trump means" (Najam, 2000); hence, the defining objectives are what determine the relationship between the two actors. If they share objectives, they are likely to gravitate towards an arrangement with the aim of achieving these goals. Salamon (1995) has argued that civil society and government are engaged primarily in a partnership in which government finances public services, while civil society (partially) delivers them. The compatibility between government and NGO goals means that the government can rely on NGOs to deliver its goals. From an economic perspective, it may also be more efficient for the government to delegate the delivery of certain services to non-governmental actors (Coase, 1988). In many cases, costs are high and efficiencies are low in public bureaucracies (Gronbjerg, 1997), making it more efficient to contract out services (Ferris, 1993). Young (1999, p. 37) claims that there are several instances when an NGO has better information to carry out service delivery efficiently: "contracting with non-profits that are knowledgeable about the individual communities in which they are based, government can overcome the information problem". Steinberg (1997) argues that non-profit organisations benefit the government in terms of reduced opportunistic behaviour and reduced transaction costs of negotiating, monitoring, and 
enforcing a contract, as compared to for-profit actors. At the same time, he warns that these benefits are subject to a handful of other external and internal factors, such as the internal motivations of non-profit agents, the level of competition, and the structure of the contracts themselves. In line with this reasoning, Hansmann (1980) argues that due to problems of asymmetric information between contributors and service providers, people trust NGOs over for-profit organisations. In a case of pursuing the same policy objective, NGOs are likely to conduct a constructive role in advocacy in which they support and incentivise the government to achieve the declared shared objectives. The power position of the government and NGOs, however, are far from symmetric, making perfect partnership and true collaboration rare.

In case of co-optation, where there is no agreement between NGOs and the government on policy goals, but where both regard the necessary means in a similar fashion, a hierarchic relationship may develop between the two actors. Governments will generally provide public goods and services following the preferences of median voters or the dominant political coalition (Buchanan \& Tullock, 1962). As the preferences of citizens are not homogeneous, there are always some groups whose preferences vary substantially from those of the median voter and who are willing to provide additional levels of public goods by mobilising through the non-profit sector on a voluntary, collective basis (Young, 1999). Hence, substantial room is left for NGOs to fill the role of supplementing government services. Within this model, civil society follows and reacts to the actions of government, undertaking tasks and fulfilling demands left unanswered by the government, rather than serving as the initiator. Such preference of the same means but different goals can conceivably lead to mutual manipulation, or even some degree of confrontation, yet given that there is an inherent power asymmetry in favour of the government, NGOs are likely here to be constrained by the hierarchic relation. Nevertheless, there may be some positive effects of NGO attempts to influence government goals, since healthy dialogue, changing ideas, and continuous communication are necessary features of the policy marketplace. Many papers have proved that in some cases, NGOs are actually successful in these attempts (e.g. Lee \& Lee, 2016). NGOs usually accept the hierarchic relation, since they either recognise their own limited capacities or else profit in some way from the similarities between means (e.g. in case of international development policy, the government may prefer to tie foreign aid to domestic procurement, from which national NGOs may also benefit).

Finally, confrontation and an adversarial relationship occur between a government and NGOs when they agree neither on the ends nor the means. If co-optation is not possible, minorities whose views are not represented in public policy will organise themselves into NGOs with the aim of gaining more from public resources and pressing the government to more adequately serve their interests (Weisbrod, 1977). 
The government has no incentives to react to such pressures, given that it acts in accordance with the requirements of the majority. Yet early contributions to the literature (Buchanan \& Tullock, 1962) based on public choice theory proved that efforts by organised minorities on particular public policy issues can be substantial, and that such interest groups can quickly become determining actors. NGOs may promote their preferences through advocacy and demonstrate the efficacy of their own view of goals and means through the provision of a service funded by voluntary contributions. According to Young (1999), such a demonstration may eventually receive the support of a majority, at which point "government may undertake full-scale provision". However, there is no guarantee that this will happen, as it depends on the ability of NGOs to solve problems of collective action and to ensure adequate resources and capacities (Olson, 1965). If NGOs are unable to solve such issues, confrontation can persist because the government has no incentive to react to minority demands. However, a government's position may also shift due to factors outside NGO influence, such as rival interest groups (including for-profit businesses), changes in the dominant coalition, or external shocks on median voter preferences.

These three positions (partnership, hierarchic/co-optation, and adversarial/confrontation) are by no means mutually exclusive or steady over time. Governments may be more dependent on NGOs in certain sectors than in others. NGOs can provide services where the government is unable or unwilling; they may also possess specific expertise that is vital for policy-making processes or policy delivery. However, in areas where service provision is less prevalent, and NGOs are active mainly in terms of their advocacy roles, the relationship may be more adversarial. Such a relationship can also change over time, often as a result of changes in preferences and relative bargaining positions. These changes can originate from factors like shifts in the amount and structure of funds available to NGOs, or shifts in government (and voter) preferences, or changes to the historical attitudes of citizens towards charity, or to public support for NGOs and/or the government. Sometimes change is slow, but it can also be rather abrupt: the sexual abuse scandals at Oxfam (a large UK-based NGO) have contributed significantly to eroding the legitimacy of NGOs in the UK (BBC, 2018).

Finally, because Hungary has here been selected as a case study, it makes sense to look at the specificities of NGO-government relations in the CEE context. There is a nearly unanimous view that NGOs in the CEE region are subordinated to the government in most cases, and have a weak role in society (e.g. Wallace et al., 2012). Individual activism is weaker in CEE countries, and NGOs often experience difficulties when attempting to mobilise citizens for specific causes. In fact, NGOs seem to be detached from their grassroots and thus lacking in legitimacy, although they have developed skills for engaging with governments (Petrova \& Tarrow, 2007). Accession to the European Union was an important element in terms of strengthening the role of civil society in general, and the empowering of NGOs in particular, 
in the CEE countries, yet papers focussing on the positive and negative consequences of EU membership are ambiguous in their findings (e.g. Szent-Iványi \& Lightfoot, 2016). On the one hand, NGOs have benefitted from the rights and responsibilities that national adoption of the EU's acquis communautaire has afforded them (Roth, 2007). On the other hand, some find that accession has not led to a systematic empowerment of civil society and has not shifted the relation of NGOs and government towards stronger partnership (Börzel \& Buzogány, 2010).

It is unclear, however, how these characteristics from the CEE countries fit in with the Najam's 'four Cs' model, or what specific NGO-government relationships have emerged. The following section investigates this issue, using the case of development and humanitarian NGOs in Hungary.

\section{Relations between development NGOs and the Hungarian government}

\section{The beginnings: $2003-2006$}

During the early years of Hungary's international development policy, the government made efforts to develop a relationship based on partnership with the development NGO community. However, true partnership emerged only with a small number of large service-provider NGOs, and we find evidence of co-optation with smaller organisations.

The government accepted its first "concept note" on international development policy in 2001, and the first foreign aid-funded projects began in 2003. While creating the new policy area was an explicit requirement of the EU accession negotiations, Hungary (and other CEE countries) received significant capacity-development assistance from established donors like the United Nations Development Programme (UNDP) or the Canadian International Development Agency (CIDA), mainly in the form of expert advice, training, and some seed funding (Szent-Iványi \& Tétényi, 2013). The early years of this policy, as well as related difficulties and contradictions, are meticulously documented by Paragi (2011), who argues that political and public attention to international development policy was low. The government aimed at putting a minimal, tokenistic policy in place to meet the requirements of the EU acquis, but it had no clear plans on what to use the policy for, or how it should develop in the future. Amounts devoted to foreign aid were likewise low, with total bilateral aid averaging around US\$37 million in 2004/2005.

While there was little strategic direction during the early years of Hungary's foreign aid policy, aid allocation patterns do reveal some trends. Hungary clearly favoured providing aid to countries in its broadly defined neighbourhood (i.e. in the Western Balkans and from the former Soviet Union). Some 
path dependency was also present, as Hungary provided relatively large amounts of aid to developing countries with which it had had close ties during the pre-1989 era, such as Vietnam and Yemen. The level of poverty or the quality of political institutions in recipient countries was not a determining factor in Hungary's aid allocation (Szent-Iványi, 2012). These aid allocation patterns hint at some interests that may have guided Hungary's foreign aid policy during the early period: the need to ensure regional stability and to maintain good relations with neighbours, as well as to support Hungarian ethnic minorities, especially in Serbia and Ukraine.

There were clear government efforts to develop partnership with NGOs in the policy area, both in terms of policy-making and in the actual delivery of international development projects. The government created a Civil Advisory Board (CAB) as a forum for public participation in shaping international development policy, and $\mathrm{CAB}$ membership included NGOs, academics, trade unions, and representatives of political parties. Civil society organisations received funding from CIDA's capacity-development programme, which assisted them in creating an umbrella advocacy group, the Hungarian Association of NGOs for Development and Humanitarian Aid (HAND). The government acknowledged HAND as the representative of development NGOs and gave it a formal consulting role in policy-making (Szent-Iványi \& Lightfoot, 2016).

Elsewhere, the government developed special relationships with a number of NGOs. Three large, faithbased NGOs - the Hungarian Interchurch Charity Service, the Baptist Charity Service, and the Hungarian Charity Service of the Order of Malta - carried out significant domestic social care and charity activities and had since the 1990s amassed experience in delivering international humanitarian aid. The government was reliant on these NGOs, especially given that the political and public saliency of humanitarian assistance was higher than that of development assistance (Szent-Iványi \& Lightfoot, 2016). Humanitarian emergencies received high media coverage, and Hungarians have shown a willingness to donate, especially in the wake of the 2005 tsunami in Southeast Asia. The goals and means of the government and the three NGOs aligned in this case: all sought to save lives (while also building the international reputation of Hungary), and they agreed that humanitarian aid in the form of goods transfers (medicines, emergency supplies, etc.) was the most appropriate solution. The government also developed a close relationship with a fourth NGO, the Hungarian International Development Assistance Non-Profit Company (HUN-IDA), which was contracted to serve as the implementing agency of Hungarian international development assistance, charged mainly with the tasks of managing the financial and contractual aspects of international development tenders.

Other NGOs at the time were mostly smaller organisations with limited capacities for humanitarian aid, and these were mainly involved in small-scale development projects, as well as awareness raising and 
development education within Hungary. The nature of their relationship with the government can be characterised more as co-option than partnership. During this early period, evidence gradually emerged that these organisations disagreed with the government's views on the goals of international development. Although it did not pay much attention to the policy, the government had emphasised how it could be a vehicle for promoting Hungarian business interests aboard, by helping Hungarian actors gain a foothold in foreign markets (see Paragi, 2011). The smaller NGOs, on the other hand, made clear their preference that foreign aid should serve poverty reduction and the attainment of the Millennium Development Goals. However, the Ministry of Foreign Affairs (MFA) was able to co-opt these through an agreement on the means of international development: tied aid. The government issued regular calls for proposals for international development projects, where only Hungarian actors (including NGOs) were eligible to apply. This represented a valuable source of financing for NGOs, especially because businesses proved less interested in such calls. Meanwhile, the hierarchical relationship of co-optation was also clearly visible from the workings of the CAB. According to Paragi (2011, p. 214), the CAB "responds to the initiatives of the MFA, instead of being a creative and pro-active body formulating proposals without any explicit invitation". Thus, the CAB appeared to be a formal body, without actual influence on policy.

Therefore, during this early period, the government developed relationships of partnership with the larger development NGOs, as it needed to rely on them for delivery of its international humanitarian obligations, while it co-opted smaller NGOs by providing them with a source of financing through an annual call for proposals. All NGOs were rather optimistic about the future during this period, and advocacy by HAND concentrated more on technical issues, such as the workings of the annual calls for proposals, and less on the substance of the government's international development policy. This meant that there was no pressure on the government to change the way the policy had been envisioned in the 2001 concept note.

\section{Austerity and confrontation: 2006-2011}

This status quo began to change after the 2006 elections, which saw the re-election of the governing social-liberal coalition. Due to years of irresponsible fiscal policy, the government's budget deficit soared to above $9 \%$ in 2006, and it was forced to implement austerity measures (Benczes, 2011). Given the low political salience of international development, bilateral aid was one of the areas cut back - by 2008, the budget had been slashed to around \$15 million. Importantly, this meant that the funding for the MFA's annual call for proposals was also cut significantly, decreasing the government's available resources for co-optation. Furthermore, in order to showcase itself as a firm ally of the US, Hungary began operating one of the Provincial Reconstruction Teams in Afghanistan in 2006. This proved to be a huge undertaking 
for such a relatively small and inexperienced donor, swallowing significant portions of the country's remaining bilateral aid budget.

The years after 2006 proved to be a difficult time for smaller NGOs. The large humanitarian NGOs had diversified funding streams and managed to maintain their partnership with the government due to their roles as service provides, even managing to win reconstruction contracts in Afghanistan. Meanwhile, smaller NGOs experienced significant funding issues and increasingly began shifting towards alternative sources of funding: they became more active in applying for EU funding, although they were less competitive than their peers from Western European countries, and had difficulties succeeding in these (Szent-Iványi 2014). Nonetheless, they came into a position where they were much less dependent on the government than previously.

This clearly had an impact on their advocacy, as lower dependence on the government allowed them to be more vocal and critical of policy issues, leading to a more confrontational relationship. The differences between these NGOs and the government in terms of how they viewed the goals of international development became much more apparent, and with the dwindling of resources for co-option, so did the differences in their views of means. These differences were starkly expressed in 2007, when HAND published its first AidWatch Report (Kiss, 2007), presenting a large number of demands to the MFA and more broadly to the government. These included a sharpening of the poverty focus of aid; increased transparency; reductions in the number of recipient countries; and reforms to the system to introduce greater strategic coherence (see Szent-Iványi \& Lightfoot, 2016).

Confrontation intensified in the following years, with regular clashes between HAND and the MFA on issues like the purposes of aid, the volume of aid, and access to data on aid. However, the wider government still paid very little attention to foreign aid, and most confrontations occurred between HAND and MFA officials, with other ministries or political actors rarely involved. This lack of interest meant that the MFA was unable to bring the demands of the NGOs on board, as many required wider government approval (such as increasing the aid budget, or reforming the structure of the aid system). Nor did the MFA have any strong incentives to carry out reforms on issues it might have impacted, given how the NGO community was unable to apply significant pressure: despite their much more active advocacy and publications, NGOs were unable to generate any public interest or support for international development (Szent-Iványi \& Lightfoot, 2016). In fact, with the onset of the global economic crisis in 2008, which hit Hungary especially hard (Benczes, 2011), people became increasingly preoccupied with their own financial circumstances. 
HAND's work was also made more difficult by collective action problems. Existing splits in the development NGO community became more apparent in this period, reflecting the fact that the large NGOs were still treated as partners by the government. Around 2005, the Hungarian Interchurch Charity Service and the Baptist Charity Service left HAND, which was significantly weakened by the loss of two of its largest members (Szent-Iványi \& Lightfoot, 2016). The smaller NGOs also seemed resentful of HUN-IDA's role and pointed to irregularities in the public procurement process, through which HUNIDA was awarded its position, and they began confronting the MFA on this issue (Miklósi, 2007; Paragi, 2011).

Further cuts were enacted to the bilateral development budget in 2010, which meant that the MFA was not able to publish a call for proposals from NGOs that year (Kiss, 2011). This again revealed the low priority that the government placed on international development. The fact that no progress had been made in meeting the demands of the NGOs was evident, as the 2012 AidWatch Report (Hódosi, 2012) essentially reiterated all the issues mentioned in the 2007 edition.

\section{Global opening: 2011-2016}

The years between 2011 and 2016 can be characterised by the government's discovery of development assistance as a foreign policy tool. Thus, a perhaps unexpected complementarity began to emerge between the government and development NGOs. One of the hallmarks of the foreign policy of the right-wing government led by Viktor Orbán after 2010 was to search for new international partners, both in the business sector and in politics, to diversify Hungary's EU-centred economic relations (Tarrosy \& Morenth, 2013). The policy, called "Global Opening", aimed at improving relations with countries that had been "neglected" in recent years, and at raising Hungarian presence in the international arena and enhancing Hungarian activity in tackling global challenges (Ministry of Foreign Affairs, 2011). Improvements in relations between Hungary and developing countries were achieved by way of a series of high-level visits, and by opening new embassies, for instance, in certain African countries (e.g. Angola, Ghana, Nigeria).

In addition, the Hungarian government sought to increase its development assistance in order to improve the visibility of Hungary in developing countries. An important achievement was the drafting and eventual acceptance of the first Hungarian law on international development (Act XC of 2014), which entered into force on 1 July 2015. The goal of the act and a related strategy document (Ministry of Foreign Affairs and Trade, 2014) was to promote human and minority rights, sustainable development, and international security. The strategy also heavily focussed on business opportunities for Hungarian companies and claimed that "[aid] can provide market access for certain segments of the Hungarian 
private and public sector (e.g., education, health) while promoting scientific and technological development" (Ministry of Foreign Affairs and Trade, 2014, p. 7). Opportunities for Hungarian businesses were to be achieved mainly through a stronger programme of tied aid, and improvement of Hungary's visibility through a higher education scholarship programme (Stipendium Hungaricum) available to citizens of the Global South. These two major programmes finally fostered government ownership of international development policy (Tétényi, 2018). They also indicate how the government's motivations for providing foreign aid changed, with business interests firmly at the centre.

Aid data show that total expenditures grew considerably between 2013 and 2016 (from US\$128 million to approximately US\$200 million), and the share of official development assistance (ODA) in gross national income (GNI) increased from $0.1 \%$ to $0.17 \%$. Bilateral tied aid was set to increase in 2018 from US $\$ 2.15$ million to almost US\$30 million. In addition, the Stipendium Hungaricum programme budget reached US\$19 million in 2016 (HAND, 2017).

The government was firmly the driver of these reforms, which should not be seen as reactions to NGO demands but rather as changes in the government's attitude towards international development.

Nonetheless, development NGOs were strongly involved in deliberation of the law and strategy on international development in 2013 and 2014, and these documents aligned to some extent with the aims of the NGO community. The reforms met some of their longstanding demands, such as providing a legal basis for international development or increasing transparency (HAND, 2014). Furthermore, Hungary also began increasing spending in low-income countries - another longstanding recommendation of the NGO sector (HAND, 2017). The share of African countries in total bilateral aid, for example, increased from 5\% to 11.5\% between 2011 and 2016. Many other emerging and developing countries - including Turkey, Nigeria, Jordan, India, Sri Lanka, Vietnam, and Laos - also received significant increases (Ministry of Foreign Affairs and Trade, 2018).

This convergence between NGO and government views on the ends and means of international development policy appeared to signal a new era of partnership. This was also evidenced by the fact that NGO criticism of the reforms and the newfound political attention were rather muted. Most NGOs were simply happy that, after years of stagnation, something was actually happening. While some of the changes, such as the emphasis on using foreign aid to promote business interests, did not resonate with their views, NGOs were not overly critical. Many NGOs, including smaller ones, further benefitted from becoming implementing partners of the MFA (rebranded as the Ministry of Foreign Affairs and Trade, MoFAT, in 2015) in small-scale (tied) development projects in countries like the Democratic Republic of Congo or Tanzania. Larger development projects, however, remained almost exclusively the realm of 
large NGOs like Hungarian Interchurch Aid, which appeared to have emerged as the government's most favoured NGO. ${ }^{1}$

HAND (in a 2017 AidWatch Report) did ask for greater cooperation between NGOs and the MoFAT - a sign that their partnership was perhaps not as strong as it could have been. However, NGOs gained an important role in the implementation of development assistance, and the government has heeded at least some of their policy-level concerns. Thus, there was some evidence of the emergence of a mutually beneficial partnership, going beyond co-optation.

\section{Repression after 2016?}

Although the relationship between development NGOs and the government improved after 2011, the Orbán government's broader actions during the same period have been characterised as 'democratic backsliding'. This process and its logic and motivations have received significant international media attention and have been well documented in the scholarly literature (Greskovits, 2015; Cianetti et al., 2018; Krekó \& Enyedi, 2018; Szuleka, 2018). A key element of Hungary's democratic backsliding relates to the government's increasing hostility towards civil society and the restrictions it has been placing on the activities of NGOs. Paradoxically, while the Hungarian government was increasing its cooperation with NGOs in the field of development cooperation, it was labelling a particular set of NGOs as operating against the interests of Hungarians, especially after 2015.

Since 2015, the Hungarian government has spent around $€ 100$ million to convince voters that Hungarianborn billionaire-philanthropist George Soros seeks to bring millions of illegal migrants into Europe, with the aim of destabilising the continent (Krekó \& Enyedi, 2018). Soros is depicted in the government media as a funder of NGOs that do his bidding and support migration. According to the government's logic, NGOs that receive funding from Soros - who directs a considerable part of his fortune towards the promotion of open society and support for advocacy groups - aim to destabilise both Hungary and Europe as a whole. This has resulted in stigmatisation and smear campaigns against NGOs, which is particularly worrying as these attacks deprive them of their legitimacy and local acceptance, in turn, hindering their ability to function and to perform their advocacy role.

There are a number of tools that a government can employ to limit the activities of civil society (Van der Borgh \& Terwindt, 2012), including administrative restrictions, stigmatisation of NGOs, limiting the space for dialogue, intimidation of civil society activists, restrictions in access to funding, and criminalisation. Following Russia's example, the government introduced legislation in 2017 (Act LXXVI of 2017), which compels all NGOs receiving more than $\$ 25,000$ in foreign funding to state this income on 
their website. According to the Hungarian Helsinki Committee and the Hungarian Civil Liberties Union (2017), this interferes with these organisations' freedom of expression, affecting their right to a good reputation by requiring NGOs to self-identify with seemingly negative labels. In 2018, government activists placed stickers on the office of the Hungarian Association for Migrants, identifying it as an organisation supporting immigration (Mérce, 2018). And the government has gone beyond measures aimed at stigmatisation: the 2018 'Stop Soros' law makes assisting 'illegal' migrants a criminal offense (The Guardian, 2018). Furthermore, the 2018 tax code (Act XLI of 2018) introduced a special immigration tax, payable by entities providing immigration-support services in Hungary.

Beyond NGOs working with migrants, the repression against NGOs has so far mainly impacted human and civil rights groups, especially those engaged in advocacy. As even the largest and most wellrespected $\mathrm{NGOs}^{2}$ receive significant portions of their income through EU grants, they are required to list themselves as NGOs funded from abroad, and this can be used against them in future smear campaigns. Development NGOs are in a similar situation, but the large faith-based organisations have been mostly left alone. These large NGOs are still key providers of humanitarian aid delivery and development assistance in which the government has little capacity. Furthermore, the existence of large, faith-based NGOs fits well with Hungary's post-2017 international development policy, centred around the new 'Hungary Helps' programme, which heavily emphasises Christian solidarity as well as addressing the root causes of migration.

Therefore, while the government has maintained partnership with key service delivery development NGOs, it has entered into a new, repressive relationship with many others, especially those engaged in advocacy. Particularly worrisome is that segments of the pro-government media are quick to label any civil organisation as a Soros-organisation that raises its voice against government policy (Magyar Idők, 2018). 'Useful' NGOs, on the other hand, are tolerated and even supported. How this general attitude by the government against NGOs will impact the post-2011 emerging partnership with NGOs in the field of international development policy is as yet unclear. With the government increasingly emphasising the role of aid in combating what it sees as illegal migration, divergence may again result in terms of how the government and NGOs view the goals of international development policy.

\section{Conclusions}

The chapter has sought to explain the nature and evolution of the relationship between the Hungarian government and NGOs active in the field of international development policy between 2003 and 2018, with a view to exploring how this relationship has impacted the ability of NGOs to shape this policy area. 
During this 15-year period, the relationship has gone through many changes, including forms of partnership, confrontation, and co-optation. Some NGOs have been consistently more favoured by the government than others: large, mainly faith-based humanitarian NGOs have been able to provide services that the government could not, and such organisations retained a close relationship with the government throughout the period. Smaller NGOs, however, have at times held clearly different views than the government on the goals and means of international development, and this has led to various degrees of co-option and confrontation.

Despite their more vigorous advocacy at times, NGOs have achieved very little in terms of influence, mainly due to the low public and political salience of international development in Hungary. Lower-level government officials have been able to disregard NGO demands, as these organisations have been unsuccessful in mobilisation and hence unable to mount significant pressure. Attempts by NGOs to fulfil their advocacy role and to generate debates with ministry officials have had little success. The chapter has indicated that the only time significant changes became possible in the policy area was when the government recognised aid's potential as a powerful tool to promote Hungarian political and business interests in developing and emerging economies, and therefore, took ownership of aid.

\section{Bibliography}

BBC (2018) 'Aid sector “Almost Complicit” in Sex Scandal, say MPs.', online at: https://www.bbc.co.uk/news/uk-politics-45013078, 31 July 2018 [accessed 15 Aug 2018].

Benczes, I. (2011) 'Market Reform and Fiscal Laxity in Communist and Post-Communist Hungary: A Path-Dependent Approach', International Journal of Emerging Markets, vol. 6, no. 2, pp. 118-131.

Börzel, T. \& Buzogány, A. (2010) 'Governing EU Accession in Transition Countries: The Role of Nonstate Actors', Acta Politica, vol. 45, nos. 1-2, pp. 158-182.

Buchanan, J. M. \& Tullock, G. (1962) The Calculus of Consent (Vol. 3). University of Michigan Press, Ann Arbor.

Busby, J. (2007) 'Bono Made Jesse Helms Cry: Jubilee 2000, Debt Relief, and Moral Action in International Politics', International Studies Quarterly, vol. 51, no. 2, pp. 247-275.

Cianetti, L., Dawson, J. \& Hanley, S. (2018) 'Rethinking "Democratic Backsliding” in Central and Eastern Europe - Looking Beyond Hungary and Poland', East European Politics, vol. 34, no. 3, pp. $243-256$. 
Coase, R. H. (1988) The Firm, the Market and the Law. University of Chicago Press, Chicago.

Elgström, O. (2000) 'Norm Negotiations. The Construction of New Norms Regarding Gender and Development in EU Foreign Aid Policy', Journal of European Public Policy, vol. 7, no. 3, pp. 457476.

European Commission (2018) 'Migration and Asylum: Commission Takes Further Steps in Infringement Procedures against Hungary', online at: http://europa.eu/rapid/press-release_IP-18-4522_en.htm [accessed 7 Aug 2018].

Ferris, J. M. (1993) 'The Double-Edged Sword of Social Service Contracting: Public Accountability versus Nonprofit Autonomy', Nonprofit Management and Leadership, vol. 3, no. 4, pp. 363-376.

Greskovits, B. (2015) 'The Hollowing and Backsliding of Democracy in East Central Europe', Global Policy, vol. 6, no. 1, pp. 28-37.

Grønbjerg, K. (1997) 'Transaction Costs in Social Service Contracting: Lessons from the USA', in Jeremy, K (ed.) The Contract Culture in Public Services. Ashgate Publishing Limited, London.

HAND (2014) 'NEFE törvényre vonatkozó civil javaslatok rövid összegzése a 2014.09.24-i egyeztetésen elhangzottak, az az után megküldött újabb verzió és a HAND-hez beérkezett írásos civil vélemények alapján', online at: http://hand.org.hu/media/files/1416413816.pdf [accessed 10 Aug 2018],

HAND (2017) 'Hand, AidWatch - A magyar hivatalos fejlesztési támogatások (ODA) alakulása az elmúlt években'. (Hungarian ODA trends in the last few years). Hand Association, Online at: http://hand.org.hu/tudastar/1/aidwatch [accessed 2 Aug 2018].

Hansmann, H. B. (1980) ‘The Role of Nonprofit Enterprise’, The Yale Law Journal, vol. 89, no. 5, pp. 835-901.

Hódosi, R. (2012) Mit tesz Magyarország a fejlödö országokért? Stratégiai fordulópont elött a magyar nemzetközi fejlesztési együttmüködés (What does Hungary do for Developing Countries? Before a Strategic Turn in Hungarian International Development Cooperation) HAND, Budapest.

Hoebink, P. (2011) European Development Cooperation: In Between the Local and the Global. Amsterdam University Press, Eadi, Amsterdam.

Hungarian Helsinki Committee and Hungarian Civil Liberties Union (2017) 'What Is the Problem with the Hungarian Law on Foreign Funded NGOs?', online at: https://www.helsinki.hu/wp- 
content/uploads/What-is-the-Problem-with-the-Law-on-Foreign-Funded-NGOs.pdf [accessed 15 Aug 2018].

Kiss, J. (2007) A magyar nemzetközi fejlesztéspolitika a számok tükrében (Hungarian International Development Policy in Numbers). HAND, Budapest.

Kiss, J. (2011) A magyar NEFE a válság éveiben (Hungarian ODA in the Years of the Crisis). HAND, Budapest.

Krekó, P. \& Enyedi, Z. (2018) ‘Explaining Eastern Europe - Orbán’s Laboratory of Illiberalism’, Journal of Democracy, vol. 29, no. 3, pp. 39-51.

Lancaster, C. (2006) Foreign Aid Diplomacy, Development, Domestic Politics. University of Chicago Press, Chicago.

Lee, S. J. \& Lee, K. S. (2016) 'The Complex Relationship between Government and NGOs in International Development Cooperation: South Korea as an Emerging Donor Country', International Review of Public Administration, vol. 21, no. 4, pp. 275-291.

Magyar Idők (2018) 'Újabb tüntetést tartottak a Soros szervezetek', (Soros Organisations Hold New Demonstration), 21 July 2018, online at: https://magyaridok.hu/belfold/ujabb-tuntetest-tartottak-asoros-szervezetek-3314654/ [accessed 7 Aug 2018].

Mérce (2018) 'Csillagos házat ragasztott le a KDNP, hogy megbélyegezzen egy civil szervezetet' (KDNP Stigmatised an NGO in a Yellow-Starred House). 14 June 2018, online at: https://merce.hu/2018/06/14/csillagos-hazat-ragasztott-le-a-kdnp-hogy-megbelyegezzen-egy-civilszervezetet/ [accessed 7 Aug 2018].

Miklósi, G. (2007) ‘Segélyezésbiznisz: Bejáratott utak (Aid Business: Well-Travelled Paths). Magyar Narancs, 10 May 2007.

Milner, H. V. \& Tingley, D. H. (2010) 'The Political Economy of US Foreign Aid: American Legislators and the Domestic Politics of Aid', Economics \& Politics, vol. 22, no. 2, pp. 200-232.

Ministry of Foreign Affairs (2011) Magyar külpolitikai az Uniós elnökség után (Hungarian foreign policy after the EU presidency), Ministry of Foreign Affairs, Budapest.

Ministry of Foreign Affairs and Trade, Hungary (2014) International Development Cooperation Strategy and Strategic Concept for International Humanitarian Aid of Hungary 2014-2020, online at: http://nefe.kormany.hu/download/3/93/c0000/International\%20Development\%20Cooperation\%20and 
\%20Humanitarian\%20Aid\%20Strategy\%20of\%20Hungary-v\%C3\%A9gleges.pdf [accessed 2 August 2018].

Ministry of Foreign Affairs and Trade, Hungary (2018) Beszámoló Magyarország 2016. évi nemzetközi fejlesztési és humanitárius segitségnyújtási tevékenységéröl (Report on Hungarian Development and Humanitarian Assistance Contributions in the Year 2016), online at: http://nefe.kormany.hu/evesbeszamolok [accessed 1 Aug 2018].

Mosely, J. (2012) 'Keeping the Lights on: How Government Funding Concerns Drives the Advocacy Agendas of Nonprofit Homeless Service Providers', Journal of Public Administration Research and Theory, vol. 22 no. 4, pp. 841-866.

Najam, A. (1999) 'Citizen Organizations as Policy Entrepreneurs', in Lewis, D. (ed.) International Perspectives on Voluntary Action, pp. 142-181. Earthscan Publisher, London.

Najam, A. (2000) 'The Four Cs of Government-Third Sector Relations: Cooperation, Confrontation, Complimentarity, Co-optation', Nonprofit Management and Leadership, vol. 10, no. 4, pp. 375-396.

Nunnenkamp, P. \& Öhler, H. (2012) 'Funding, Competition and the Efficiency of NGOs: An Empirical Analysis of Non-charitable Expenditure of US NGOs Engaged in Foreign Aid', Kyklos, vol. 65, no. 1, pp. $81-110$.

Olson, M. (1965) The Logic of Collective Action. Harvard University Press, Cambridge.

Paragi, B. (2011) 'Hungarian Development Policy', in Hoebink, P. (ed.) European Development Cooperation: In Between the Local and the Global, Amsterdam University Press, Eadi, Amsterdam.

Park, S. (2005) 'How Transnational Environmental Advocacy Networks Socialize International Financial Institutions: A Case Study of the International Finance Corporation', Global Environmental Politics, vol. 5 , no. 4 , pp. 95-119.

Roth, S. (2007) 'Sisterhood and Solidarity? Women's Organizations in the Expanded European Union', Social Politics, vol. 14, no. 4, pp. 460-487.

Salamon, L. M. (1995) Partners in Public Service: Government-Nonprofit Relations in the Modern Welfare State. Johns Hopkins University Press, Baltimore.

Sanchez Salgado, R. (2017) 'Europeanization of Civil Society Organizations in Times of Crisis? Exploring the Evolution of Grant-Seeking Strategies in the EU Multi-level System', European Politics and Society, vol. 18, no. 4, pp. 511-528. 
Steinberg, R. (1997) 'Competition in Contracted Markets', in Kendall, J. (ed.) The Contract Culture in Public Services, pp. 161-179. Ashgate, London.

Steinberg, R. \& Powell, W.W. (2006). The Nonprofit Sector: A Research Handbook. Yale University Press, New Haven.

Szent-Iványi, B. (2012) 'Aid Allocation of the Emerging Central and Eastern European Donors', Journal of International Relations and Development, vol. 15 no. 1, pp. 65-89.

Szent-Iványi, B. (2014) 'The EU’s Support for Democratic Governance in the Eastern Neighbourhood: The Role of New Member State Transition Experience', Europe-Asia Studies, vol. 66, no. 7, pp. 11021121.

Szent-Iványi, B. \& Tétényi, A. (2013) 'The East-Central European New Donors: Mapping Capacity Building and Remaining Challenges', Journal of International Development, vol. 25, no. 6, pp. 819831.

Szent-Iványi, B. \& Lightfoot, S. (2016) 'Determinants of Civil Society Influence: The Case of International Development and Humanitarian NGOs in the Czech Republic and Hungary'. Comparative European Politics, vol. 14, no. 6, pp. 761-780.

Szuleka, M. (2018) 'First Victims or Last Guardians? The Consequences of Rule of Law Backsliding for NGOs: Case Studies of Hungary and Poland', CEPS Paper in Liberty and Security in Europe, no 2018-06.

Tarrósy, I. \& Morenth, P. (2013) ‘Global Opening for Hungary - New Beginning for Hungarian Africa Policy?', African Studies Quarterly, vol. 14, nos. 1-2, pp. 77-96.

Tétényi, A. (2018) ‘Hungarian International Development Policy: A Case for Conflicted Success’, in Batory, Á., Cartwright, A. \& Stone, D. (eds.), Policy Experiments, Failures and Innovations Beyond Accession in Central and Eastern Europe, pp. 152-169. Edward Elgar Publishing, Cheltenham.

The Guardian (2018) 'Hungary Passes Anti-immigrant “Stop Soros” Laws', 20 June 2018, online at: https://www.theguardian.com/world/2018/jun/20/hungary-passes-anti-immigrant-stop-soros-laws [accessed 7 Aug 2018].

Heppel, T. \& Lightfoot, S. (2012) “"We Will Not Balance the Books on the Backs of the Poorest People in the World": Understanding Conservative Party Strategy on International Aid', The Political Quarterly, vol. 83, no. 1, pp. 130-138. 
Petrova, T. \& Tarrow, S. (2007) 'Transactional and Participatory Activism in the Emerging European Polity: The Puzzle of East-Central Europe', Comparative Political Studies, vol. 40, no. 1, pp. 74-94.

Van Der Borgh, C. \& Terwindt C. (2012) 'Shrinking Operational Space of NGOs - a Framework of Analysis', Development in Practice, vol. 22, no. 8, pp. 1065-1081.

Wallace, C., Pichler, F. \& Haerpfer, C. (2012) 'Changing Patterns of Civil Society in Europe and America 1995-2005: Is Eastern Europe Different?', East European Politics and Societies, vol. 26, no. 1, pp. 3-19.

Weisbrod, B. A. (1977) The Voluntary Nonprofit Sector: An Economic Analysis. D.C. Heath and Company, Lexington.

Young, D. R. (1999) 'Complementary, Supplementary, or Adversarial? Nonprofit-Government Relations', in Boris, E. T. \& Steuerle, C. E. (eds.), Nonprofits \& Government: Collaboration and Conflict, pp. 31-67. The Urban Institute Press, Washington DC.

\footnotetext{
${ }^{1}$ This is also shown by the fact that Prime Minister Viktor Orbán's wife is one of Hungarian Interchurch Aid's goodwill ambassadors.

${ }^{2}$ For a list, see: http://civil.info.hu/kulfoldrol-tamogatott-civil-szervezetek. These include such wellknown brands as WWF, Red Cross, Hungarian Interchurch Aid, Hungarian Baptist Aid, Greenpeace, UNICEF, etc.
} 